\title{
Occurrence of Mycoplasma synoviae on commercial poultry farms of Pernambuco, Brazil ${ }^{1}$
}

\author{
Mércia R. Barros ${ }^{2 *}$, Elmiro R. Nascimento ${ }^{3}$, José Sérgio A. Silva², José W. Pinheiro Júnior ${ }^{4}$, \\ Sandra B. Santos ${ }^{3}$, Leandro S. Machado ${ }^{3}$, Rita Cássia F. Silva ${ }^{3}$ and Rinaldo A. Mota ${ }^{2}$
}

\begin{abstract}
Barros M.R., Nascimento E.R., Silva J.S.A., Pinheiro Júnior J.W., Santos S.B., Machado L.S., Silva R.C.F. \& Mota R.A. 2014. Occurrence of Mycoplasma synoviae on commercial poultry farms of Pernambuco, Brazil. Pesquisa Veterinária Brasileira 34(10):953-956. Departamento de Medicina Veterinária, Universidade Federal Rural de Pernambuco, Av. Dom Manuel de Medeiros s/n, Recife, PE 52171900, Brazil. E-mail: merciarbpe@dmv.ufrpe.br

The state of Pernambuco is the largest producer of eggs in the North and Northeast of Brazil and second one in the broiler production. Mycoplasmas are important avian pathogens, which cause respiratory and joint diseases that result in large economic losses. The aim of the present study was to investigate the occurrence of Mycoplasma gallisepticum (MG) and Mycoplasma synoviae (MS) in broilers and commercial laying hens in the state of Pernambuco, Brazil. Tracheal fragments were analyzed from 55 healthy broilers, 35 broilers with respiratory signs and 30 commercial laying hens with respiratory signs, from 24 commercial poultry farms, each sample was composed of a pool of five birds. The bacteriological exam, PCR and nested PCR were used for the detection of Mycoplasma gallisepticum (MG) and Mycoplasma synoviae (MS). All samples were negative in bacteriological isolation. In the PCR analyses, seven samples from birds with respiratory signs were positive for MS and one was positive for MG, the latter of which was confirmed as the MG-F vaccine strain. The occurrence of MS in chickens with respiratory signs may indicate inadequate sanitary management on poultry farms, favoring the propagation of mycoplasmosis.
\end{abstract}

INDEXS TERMS: Mycoplasmosis, Mycoplasma synoviae, PCR, broilers, commercial laying hens, diagnosis.

RESUMO.- [Ocorrência de Mycoplasma synoviae em granjas comerciais da avicultura de Pernambuco.] 0 estado de Pernambuco é o maior produtor de ovos da região Norte e Nordeste e ocupa a segunda posição na produção de frangos de corte. Os micoplasmas são importantes patógenos aviários que causam doenças respiratórias e sinovite que resultam em grandes perdas econômicas.

\footnotetext{
${ }^{1}$ Received on February 7, 2014.

Accepted for publication on August 28, 2014.

Article extracted from Tese de Doutorado do Programa de Pós-Graduação em Ciência Veterinária, Universidade Federal Rural de Pernambuco (UFRPE), Recife, PE, Brazil.

${ }^{2}$ Laboratório de Bacterioses dos Animais Domésticos, Departamento de Medicina Veterinária, UFRPE, Av. Dom Manoel de Medeiros s/n, Recife, PE 52171-900. *Corresponding author: merciarbpe@dmv.ufrpe.br

${ }^{3}$ Departamento de Saúde Coletiva Veterinária e Saúde Pública, Universidade Federal Fluminense (UFF), Rua Vital Brazil Filho 64, Niterói, RJ 24230-340, Brazil.

${ }^{4}$ Unidade Acadêmica de Garanhuns, UFRPE, Av. Bom Pastor s/n, Boa Vista, Garanhuns, PE 55292-270, Brazil.
}

Objetivou-se pesquisar a ocorrência de Mycoplasma gallisepticum (MG) e Mycoplasma synoviae (MS) em frangos de corte e poedeiras comerciais no Estado de Pernambuco, Brasil. Foram colhidos fragmentos de traquéia de 55 frangos de corte sadios, 35 com sinais respiratórios e de 30 poedeiras comerciais também com sinais respiratórios, provenientes de 24 granjas, cada amostra foi composta por um "pool" de cinco aves. Para detecção de Mycoplasma gallisepticum (MG) e Mycoplasma synoviae (MS) foram utilizados o exame bacteriológico, PCR e Nested-PCR. Todas as amostras apresentaram resultados negativos no exame bacteriológico. Na PCR, sete amostras foram positivas para MS e uma para MG em amostras de aves com sinais respiratórios, sendo a amostra positiva para MG confirmada como cepa vacinal MG-F. A ocorrência de MS em aves com sinais clínicos respiratórios pode indicar ausência de barreiras sanitárias adequadas em granjas de frangos de corte e de poedeira comercial, favorecendo a sua propagação. 
TERMOS DE INDEXAÇÃO: Micoplasmoses, Mycoplasma synoviae, PCR, frangos de corte, poedeira comercial, diagnóstico.

\section{INTRODUCTION}

The intensification of production in the poultry industry leads to particular conditions that favor the occurrence and dissemination of infectious diseases, especially those that affect the respiratory tract (Minharro et al. 2001).

Mycoplasmosis is considered the respiratory disease with the greatest impact on all segments of poultry farming. Mycoplasma gallisepticum (MG) causes chronic respiratory disease and accounts for economic impact related to feed conversion loss, lower egg production, embryonic mortality and the non-approval of the carcass for human consumption (Yoder 1984). Mycoplasma synoviae (MS) causes subclinical infection of the upper respiratory tract, characterized by a lack of clinical signs or only respiratory illness (Stipkovits \& Kempf, 1996). M. synoviae can also cause airsacculitis in chickens (Rosales 1991) and is often found in its asymptomatic form on poultry farms in Brazil (Fiorentin et al. 2003). Following infection by Mycoplasma gallisepticum or Mycoplasama synoviae, chickens become more susceptible to secondary infections by other viral or bacterial agents, such as Escherichia coli (Alencar et al. 1998, Ferreira \& Knöbl, 2000).

The aim of the present study was to investigate the occurrence of Mycoplasma gallisepticum and Mycoplasma synoviae on commercial poultry farms in the state of Pernambuco, Brazil.

\section{MATERIALS AND METHODS}

Sampling. Eleven farms with healthy broilers chickens, seven with broiler chickens presenting clinical respiratory signs and six farms with commercial laying chickens presenting clinical signs of respiratory disease were used, corresponding to approximately $20 \%$ of the poultry farms in the state of Pernambuco (northeastern Brazil). A total of 55 trachea fragments were collected from the healthy broilers, 35 were collected from broilers with clinical signs and 30 were collected from commercial laying chickens with clinical signs. Each sample was made up of a pool of five birds per farm, totaling 24 samples for the processing of the microbiological and molecular methods.

Bacteriological exam. After the collection of trachea samples by swabs, scarification and maceration, the specimens were stored in glycerol (1:2) and frozen at $-20^{\circ} \mathrm{C}$ until processing. For isolation, the samples were diluted in series from $10^{-1}$ to $10^{-5}$ and then placed in a modified liquid and solid Frey medium and incubation at $37^{\circ} \mathrm{C}$ by $48-72 \mathrm{~h}$. The reactions in the agar were observed for 21 days under a stereomicroscope (40x) for the determination of the growth of characteristic colonies of Mycoplasma spp. (Nascimento 2000).

DNA extraction. DNA extraction of the swab, scarification and maceration samples was performed with the phenol/chloroform method (Sambrook et al. 1989).

PCR protocols. For the DNA amplification reaction, specifics primers for Mycoplasma gallisepticum (MG), Mycoplasma synoviae (MS) and the MG-F vaccine strain were used (Table 1). Bacterial DNA was amplified in the PCR reaction mixtures as follows. Each reaction system had a final volume of $100 \mu$ and contained $59 \mu \mathrm{l}$ of ultra-pure water (Milli-Q), $10 \mu \mathrm{l}$ of $10 \mathrm{X}$ PCR buffer, $5 \mu \mathrm{l}$ of $\mathrm{MgCl}_{2}(25 \mathrm{mM}), 5 \mu \mathrm{l}$ of dNTP mix (each $0.25 \mathrm{mM}$ ), $2 \mu \mathrm{l}$ of each primer (100pmol), $2 \mu \mathrm{l}$ of Taq DNA polymerase $(2.5 \mathrm{U} / \mu \mathrm{l})$ and $15 \mu \mathrm{l}$ of the DNA template. The MG (ATCC 19610) and MS (ATCC 25204) strains from the American Type Culture Collection were used as the positive controls. The negative control consisted of the PCR water used in place of DNA. The mixtures were preheated at $94^{\circ} \mathrm{C}$ for $1 \mathrm{~min}$ before submitted to recycling step. The amplification conditions for the PCR assays were 40 cycles at $94^{\circ} \mathrm{C}$ for $1 \mathrm{~min}$, $55^{\circ} \mathrm{C}$ for $1 \mathrm{~min}$, and $72^{\circ} \mathrm{C}$ for $2 \mathrm{~min}$. A final extension step was performed at $72^{\circ} \mathrm{C}$ for $5 \mathrm{~min}$ and cooling at $4^{\circ} \mathrm{C}$ for $5 \mathrm{~min}$.

Nested-PCR. The nested PCR was performed with the amplicons from the previous reactions using specific MG-PCR primers (Table 1). Each reaction system had a final volume of $100 \mu$ and contained $71 \mu \mathrm{l}$ of ultra-pure water (Milli-Q), $10 \mu \mathrm{l}$ of $10 \mathrm{x}$ PCR buffer, $5 \mu \mathrm{L}$ of $\mathrm{MgCl}_{2}(25 \mathrm{mM}), 5 \mu \mathrm{l}$ of dNTP mix $(0.25 \mathrm{mM}$ of each), $2 \mu \mathrm{l}$ of each primer $(100 \mathrm{pmol}), 2 \mu \mathrm{l}$ of Taq Polymerase $(2.5 \mathrm{U} / \mu \mathrm{l})$ and $3 \mu \mathrm{l}$ of the DNA template. The negative control consisted of the PCR water used in place of DNA. The mixtures were preheated at $94^{\circ} \mathrm{C}$ for $5 \mathrm{~min}$ before submitted to recycling step. The amplification conditions for the Nested-PCR assays were 40 cycles at $94^{\circ} \mathrm{C}$ for 1 $\min , 55^{\circ} \mathrm{C}$ for $1 \mathrm{~min}$, and $72^{\circ} \mathrm{C}$ for $2 \mathrm{~min}$. A final extension step was performed at $72^{\circ} \mathrm{C}$ for $10 \mathrm{~min}$ and cooling at $4^{\circ} \mathrm{C}$ for 30 seconds.

The PCR products were analyzed in agarose gel $(1.5 \% \mathrm{w} / \mathrm{v})$ and stained with ethidium bromide (5\%) and the fragments were viewed under ultraviolet light. The 100-bp Ladder ${ }^{\circledR}$ molecular weight marker was used.

Statistical analysis. The Kappa coefficient (K) was used of the concordance study, with the following conventional interpretation values: 0.00 to $0.20=$ weak agreement; 0.21 to $0.40=$ fair agreement; 0.41 to $0.60=$ moderate agreement; 0.61 to $0.80=$ good agreement; and 0.81 to $1.00=$ very good agreement. Negative values were interpreted as equivalent to 0.0 . The chi-square test of independence was used to determine associations between the biological materials (Landis \& Koch 1977).

\section{RESULTS}

The clinical signs in the ill chickens were mild to abundant nasal drip, facial swelling and respiratory stertor. The necroscopic findings were airsacculitis, hemorrhaging and mu-

Table 1. PCR markers and Nested-PCR for detection of Mycoplasma gallisepticum, Mycoplasma synoviae and MG-F vaccine strain

\begin{tabular}{|c|c|c|c|}
\hline Primers & Sequence nucleotide $\left(5^{\prime} \rightarrow 3^{\prime}\right)$ & $\begin{array}{l}\text { Size of amplified } \\
\text { product (bp) }\end{array}$ & Reference \\
\hline MG & F: GGATCCCATCTCGACCACGAGAAAA & $732 \mathrm{bp}$ & Nascimento et al. (1991) \\
\hline MG & R: CTTTCAATCAGTGAGTAACTGATGA & & \\
\hline MGF & F: TAАСССТTСАТСАССТСАТСТАGAG & $524 \mathrm{bp}$ & Nascimento et al. (1993) \\
\hline MGF & R: CTGTTTGCTAAAGAACAAGTTGATC & & \\
\hline MS & F: GAGAAGCAAAATAGTGATATCA & $207 \mathrm{bp}$ & Lauerman et al. (1998) \\
\hline MS & R: CAGTCGTCTCCGAAGTTAACAA & & \\
\hline MG-PCR & F: CGTGGATATCTTTAGTTCCAGCTGC & $481 \mathrm{bp}$ & Nascimento et al. (2005) \\
\hline MG-PCR & R: GTAGCAAGTTATAATTTCCAGGCAT & & \\
\hline
\end{tabular}


cus in the trachea. The microbiological analysis of the swab, scarification and maceration samples from the broilers and commercial laying chickens revealed negative results.

PCR analysis revealed that eight samples (33.33\%) were positive and $16(66.67 \%)$ were negative. Among all the samples submitted to nested PCR, seven (29.17\%) were positive for MS and only one (4.17\%) was positive for MG for all samples subjected to PCR and Nested-PCR. Among the seven samples collected from broilers with clinical signs of respiratory disease, three (42.85\%) were positive for MS. Among the six samples from commercial laying chickens, four $(66.67 \%)$ were positive for MS and one (16.67\%) was positive for MG, which was confirmed as the MG-F vaccine strain.

The Kappa test indicated $0.00 \%$ sensitivity and $66.67 \%$ specificity in the comparison of the PCR results and microbiological exam. Regarding the type of biological material collected from the broilers and commercial laying chickens, positive PCR results were obtained in two swab samples $(8.33 \%)$, one scarification sample $(4.17 \%)$ and six macerated samples $(25.0 \%)$, not finding a statistically significant $(p=0,069)$ differences between the biological materials used for diagnosis.

The results demonstrate a high frequency of positive samples for Mycoplasma synoviae in chickens with clinical respiratory signs, with the commercial laying system achieving $83.33 \%$ positivity. The frequency of MS (53.85\%) among the total number of farms analyzed with birds showing clinical signs of respiratory disease was greater than that of MG, for which only one positive sample (4.17\%) was detected and confirmed as the vaccine strain.

\section{DISCUSSION}

Mycoplasmas are pathogens that cause chronic respiratory disease, synovitis and bursitis in chickens and turkeys, accounting for considerable economic losses in the poultry industry. In Brazil, the frequency of infection by MS is greater than that by MG (Reis et al. 1973, Mettifogo et al. 2002, Buim 2005, Buim et al. 2009). Moreover, the prevalence of MS in chickens has increased in the past twenty years (Balen \& Fiorentin 1990).

In northeastern Brazil, little is known regarding the occurrence of infection by these bacteria on chicken poultry farms. A recent study reports that the prevalence of MS and MG on farms in general is $72.7 \%$. The results also indicate the dissemination of mycoplasmas among the farms surveyed, with an increase in the incidence of MS and a reduction in the incidence of MG among commercial poultry farms in Brazil (Buim et al. 2009). Report that birds free of MS that are introduced onto a farm with a history of infection may become infected as well due to the perpetuation of the microorganism in the surrounding environment (Fiorentin et al. 2002).

The results of the present study confirm this tendency in the state of Pernambuco, as a greater frequency of MS was detected on the farms studied. The presence of mycoplasmas on properties is associated to faulty sanitation barriers, which is an important risk factor for the dissemination of the disease. This aspect is important from the epidemiological standpoint, as mycoplasmas can be trans- mitted both horizontally and vertically, which facilitates the dissemination of these bacteria on a single farm or to other farms that receive infected birds, thereby increasing the frequency of cases as well as the economic losses stemming from the infection (Buim et al. 2009).

One of the characteristics of mycoplasmas, especially MS, is asymptomatic infection that can cause immunosuppression (Stipkovits \& Kempf 1996). In the present study, however, all positive samples for MS were from chickens with clinical signs of respiratory disease.

The clinical and macroscopic findings in the birds with respiratory problems were compatible with the clinical form of avian mycoplasmosis. However, feed conversion loss, lower egg production, embryonic mortality and the non-approval of the carcass for human consumption, which are often related to infection by mycoplasmas (Yoder 1984, Manfredini 1985, Kleven 1994) were not assessed in the present study. The literature reports that, after infection by MG and/or MS, chickens become more susceptible to secondary infections from other agents such as viruses and/ or Escherichia coli (Alencar et al. 1998, Ferreira \& Knöbl, 2000). Regarding this aspect, Escherichia coli was isolated in $38.46 \%$ of the samples that were positive for MS (Unpublished data).

In epidemiological studies, different diagnostic methods are described for the confirmation of infection by $M y$ coplasma (Kleven 1994). In a comparison of PCR analysis and the culturing of swabs of the trachea of chickens that were seropositive for MS and experimentally infected with MG, report that among the 76 tracheal swab samples, 62 were positive in the PCR, whereas 41 were positive in the cultures (Salisch et al. 1998). Although cultures are generally considered the best method for the definitive diagnosis of Mycoplasma infection, this method has the disadvantage of being laborious and depends on the viability of the microorganism in the sample, while PCR does not depend on this viability; PCR is also faster and offers greater sensitivity and specificity (Kleven 1994).

Another advantage of PCR is that infections combined with other mycoplasmas or other bacteria do not affect the reaction, making PCR a useful alternative for the diagnosis of avian mycoplasmosis (Nascimento et al. 1991). PCR is also chosen due to the fact that it is a specific, sensitive method capable of detecting and amplifying low-quality DNA (Saiki et al. 1985, Innis \& Gelfand, 1990), which assists in farm monitoring programs and the differentiation of the field and vaccine strains of MG (Nascimento et al. 1993, Mettifogo et al. 2002). In the present study, the PCR results for $M G$ differentiated the MG-F vaccine in samples from the commercial egg-laying farm with a history of vaccination.

\section{CONCLUSIONS}

Regardless of the type of poultry farm, Mycoplasma synoviae was the only species identified.

Poultry producers in the state of Pernambuco, Brazil, should discuss control and biosafety measures for the prevention and propagation of this agent.

The use of PCR is indicated for the diagnosis and monitoring of mycoplasmosis on commercial poultry farms, is 
also needed to differentiate MG field strain with the vaccine strain MG-F, included in the vaccination program in commercial laying farms.

Research Ethics Committee.- The experimental protocol of this study followed the Ethical Principles of Animal Experimentation adopted by the Brazilian College of Animal Experimentation and received approval from the Ethics Committee on Animal Use of the University Federal Rural of Pernambuco (Brazil) under process no. 23082.001526.

Acknowledgements.- This study was supported by the National Council of Scientific and Technological Development (CNPq, Proc. no.561360/20081) and the Veterinarian doctor Glédiston Posso of Company Ltda ALIVET agricultural products. The authors are grateful for the assistance and contribution of Dra. Vírgínia Léo Almeida University Federal Fluminense and Dra. Lúcia Maria Barreto of Center Laboratory Animal University Federal Fluminense, Niterói/RJ, Brazil.

\section{REFERENCES}

Alencar A.P., Nascimento E.R., Danelli M.G.M., Lignon G.B., Santos M.A.J. \& Nascimento M.G.F. 1998. Relação entre infecção por Mycoplasma gallisepticum e Mycoplasma synoviae e lesões de sacos aéreos em frangos de corte. Revta Bras. Med. Vet. 20:257-262.

Balen L. \& Fiorentin L.O. 1990. Mycoplasma synoviae e seu impacto econômico sobre a avicultura. Anais Conferência APINCO de Ciência e Tecnologia Avícolas, Campinas/SP, p.135-140.

Buim M.R. 2005. Mycoplasma synoviae: diagnóstico, caracterização molecular e interação parasita-hospedeiro, Tese de Doutorado em Ciências Biológicas, Universidade de São Paulo, São Paulo/SP. 70p.

Buim M.R., Mettifogo E., Timenetsky J., Kleven S. \& Ferreira A.J.P. 2009. Epidemiological survey on Mycoplasma and Mycoplasma synoviae by multiplex PCR in commercial poultry. Pesq. Vet. Bras. 29:552-556.

Ferreira A.J.P. \& Knöbl T. 2000. Colibacilose aviária, p.197-207. In: Berchieri Júnior A. \& Macari M. (Eds), Doenças das Aves. Facta, Campinas/ SP.

Fiorentin L., Mores M.A.Z., Trevisol I.M., Antunes S.C., Costa J.L.A., Soncini R.A. \& Vieira N.D. 2002. Comportamento da infecção por Mycoplasma synoviae em matrizes de corte introduzidas em granja com histórico de positividade. Revta Bras. Ciênc. Avíc. 4(Supl.):122.

Fiorentin L., Soncini R.A., Costa J.L.A., Mores M.A.Z., Trevisol I.M., Toda M. \& Veira N.D. 2003. Apparent eradication of Mycoplasma synoviae in broiler breeders subjected to intensive antibiotic treatment directed to control Escherichia coli. Avian. Pathol. 32:213-216.

Innis M.A. \& Gelfand D.H. 1990. Optimization of PCRs, p.3-11. In: Innis M.A., Gelfand D.H., Sninsky J.J. \& White H. (Eds), PCR Protocols: a guide to methods and applications. A cademic Press, San Diego, California.
Kleven S.H. 1994. Summary of discussions, Avian Mycoplasma Team, International Research Program on comparative Mycoplasmology, University of Ljubljana, Domzale, Slovenia. Avian. Pathol. 23:587-594.

Landis J.R. \& Koch G.G. 1977. The measurement of observer agreement for categorical data. Biometh. 33:159-174.

Manfredini R. 1985. Mycoplasma spp.: as bacterinas como método de controle. Encontro Empresarial de Atualização em Patologia Avícola, Campinas/SP, p.1.

Mettifogo E., Buim M.R., Ferreira A.J.P., Buzinhani M., Sakata S.T. \& Timenetsky J. 2002. Padronização de multiplex PCR para a detecção de Mycoplasma synoviae, M. gallisepticum e M. gallisepticum cepa F vacinal. Revta Bras. Ciênc. Avíc. 4(Supl.):121.

Minharro S., Linhares G.F.C., Andrade M.A., Rocha P.T. \& Santana A.P. 2001. Envolvimento de Escherichia coli, de Mycoplasma gallisepticum e de Mycoplasma synoviae em lesões de sacos aéreos em frangos de corte abatidos no Estado de Goiás. Ciênc. Anim. Bras. 2:111-117.

Nascimento E.R., Yamamoto R., Herrick K.R. \& Tait R.C. 1991. Polymerase Chain Reaction for Detection of Mycoplasma gallisepticum. Avian Dis. 35:62-69.

Nascimento E.R., Yamamoto R. \& Khan M.I. 1993. Mycoplasma gallisepticum F-vaccine strain-specific Polymerase Chain Reaction. Avian Dis. 37:203-211

Nascimento E.R. 2000. Micoplasmoses, p.217-240. In: Macari M. \& Berchieri Jr A. (Eds), Doenças das Aves. FACTA, Campinas/SP.

Reis S.R., Resende M., Ornellas-Santos P.P, Yamamoto R. \& Oliveira R.L. 1973. Micoplasmoses animais: frequência de M. meleagridis e M. gallisepticum em perus em Minas Gerais. Arq. Bras. Med. Vet. Zootec. 24:197199.

Rosales A.G. 1991. Enfermedades respiratorias en el pollo de engorde: manifestaciones clinicas, etiologia y control. Conferência Apinco de Ciência e Tecnologia Avícolas, Campinas/SP, p.163-176.

Saiki R.K., Scharf S., Faloona F., Mullis K.B., Horn G.T., Erlich H.A. \& Arnhein N. 1985. Enzymatic amplification of B-globin genomic sequences and restriction site analysis for diagnosis of sickle cell anemia. Science 230:1350-1354.

Salisch H., Hinz K.H., Graack H.D. \& Ryll M. 1998. A comparison of a commercial PCR-based test to culture methods for detection of Mycoplasma synoviae in concurrently infected chickens. Avian Pathol. 27:142-147.

Sambrook K.J., Fritsch E.F. \& Maniatis T. 1989. Molecular Cloning: laboratory manual. $2^{\text {nd }}$ ed. Cold Spring Harbor Laboratory, New York. 215p.

Stipkovits L. \& Kempf I. 1996. Mycoplasmoses in poultry. Rev. Sci. Technol. Int. Epizoot. 15:1495-1525.

Yoder Jr H.W. 1984. Mycoplasma gallisepticum infection, p.190-212. In: Hofstad M.S., Barnes H.J., Calnek B.W., Helmboldt C.F., Reid W.M. \& Yoder Jr W.H. (Eds), Diseases of Poultry. $8^{\text {th }}$ ed. American Association of Avian Pathologists, Ames, IA. 